\begin{tabular}{|c|c|}
\hline $\begin{array}{l}\text { MUEOTL } \\
\text { MANDUEMEN } \\
\text { KEWIRAUSAHAAN }\end{array}$ & $\begin{array}{r}\text { p-ISSN 1858-1048 } \\
\text { e-ISSN 2654-9247 } \\
\text { http://ejurnal.stieipwija.ac.id/index.php/jmk } \\
\text { DOI: http://dx.doi.org/10.33370/jmk.v17i2.483 } \\
\text { Jurnal Manajemen Kewirausahaan Vol. 17 No. 02 - Des } 2020 \\
\text { Submit: } 18 \text { Nov 2020; Review: 23 Nov 2020; Publish: } 28 \text { Des } 2020\end{array}$ \\
\hline
\end{tabular}

\title{
PENGARUH REKRUTMEN, PELATIHAN, DAN KOMPENSASI TERHADAP KINERJA KARYAWAN PT INDO SUHAR JAYA CABANG BOGOR
}

\section{(EFFECT OF RECRUITMENT, TRAINING AND COMPENSATION ON THE PERFORMANCE OF EMPLOYEES OF PT INDO SUHAR JAYA BOGOR BRANCH)}

\author{
Oleh: \\ Wisnu Wardani Sutarno Putro'); Siti Laela2) \\ whardani96wisnu@gmail.com ${ }^{1)}$; siti_laela65@yahoo.com ${ }^{2}$ ) \\ Sekolah Tinggi Ilmu Ekonomi IPWI Jakarta1,2)
}

\begin{abstract}
ABSTRAK
Rekrutmen, pelatihan, dan kompensasi dapat mempengaruhi kinerja karyawan pada PT Indo Suhar Jaya. Untuk menjawab maka diperlukan membuktikan pengaruh penelitian dari ketiga faktor independen terhadap faktor dependen. Penelitian ini bertujuan untuk mengetahui: (1) pengaruh rekrutmen terhadap kinerja karyawan pada $P T$ Indo Suhar Jaya, (2) pengaruh pelatihan terhadap kinerja karyawan pada PT Indo Suhar Jaya, (3) pengaruh kompensasi terhadap kinerja karyawan pada PT Indo Suhar Jaya. Dalam penelitian ini penulis mengambil sampel sebanyak 52 karyawan dengan jumlah populasi 110 karyawan, dengan menggunakan rumus slovin. Pengambilan data dilakukan dengan menggunakan kuesioner yang disebar kepada responden. Metode analisis yang digunakan adalah uji validitas, uji reliabilitas, uji regresi linier berganda, uji koefisien determinan $\left(R^{2}\right)$, dan pengujian hipotesis melalui uji $t$ dan uji $F$. Penelitian ini menghasilkan tiga temuan sesuai dengan hipotesis yang diajukan, yaitu: (1) bahwa rekrutmen berpengaruh positif terhadap kinerja karyawan, (2) bahwa pelatihan berpengaruh positif terhadap kinerja karyawan, (3) bahwa kompensasi berpengaruh positif terhadap kinerja karyawan. Dapat disimpulkan bahwa, rekrutmen yang sesuai dengan system dan aturan perusahaan yang baik, pelatihan dan kompensasi yang diberikan kepada karyawannya dapat meningkatkan kinerja karyawan pada PT Indo Suhar Jaya Bogor.
\end{abstract}

Kata kunci: Kinerja; Kompensasi; Pelatihan; Rekrutmen

\begin{abstract}
Recruitment, training, and compensation can affect employee performance at PT Indo Suhar Jaya. To answer, it is necessary to prove the effect of the three independent factors on the dependent factor. This study aims to determine: (1) the effect of recruitment on employee performance at PT Indo Suhar Jaya, (2) the effect of training on employee performance at PT Indo Suhar Jaya, (3) the effect of compensation on employee performance at PT Indo Suhar Jaya. In this study the authors took a sample of 52 employees with a population of 110 employees, using the slovin formula. Data were
\end{abstract}

Jurnal Manajemen Kewirausahaan Vol. 17 No. 02 - Desember 2020 
collected using a questionnaire distributed to respondents. The analytical method used is the validity test, reliability test, multiple linear regression test, determinant coefficient test $(R 2)$, and hypothesis testing through $t$ test and $F$ test. This study resulted in three findings in accordance with the proposed hypothesis, namely: (1) that recruitment has a positive effect on employee performance, (2) that training has a positive effect on employee performance, (3) that compensation has a positive effect on employee performance. It can be concluded that, recruitment in accordance with good company systems and rules, training and compensation provided to employees can improve employee performance at PT Indo Suhar Jaya Bogor.

Keywords: Compensation; Performance; Recruitment; Training

\section{PENDAHULUAN}

Sumber daya manusia dalam suatu perusahaan merupakan suatu modal yang harus dimiliki suatu organisasi untuk menjalankan perusahaan. Pengelolaan sumber daya manusia yang sesuai dengan pedoman dan perencanaan yang sudah ditetapkan perusahaan akan meningkatkan kinerja perusahaan. Kinerja sumber daya yang dimiliki oleh perusahaan merupakan suatu tuntutan keharusan untuk mencapai tujuan organisasi.

Semakin tinggi kinerja karyawan suatu perusahaan, semakin mudah tujuan perusahaan akan tercapai. Untuk meningkatkan kinerja karyawan yang optimal perlu ditetapkan standar yang jelas, metode yang sesuai dengan prinsipprinsip rekrutmen, serta tujuan dari rekrutmen akan bisa dicapai tujuan dari organisasi. Demikian juga dalam memberikan pelatihan perusahaan juga diharapkan menggunakan berbagai macam metode untuk menyampaikan materi pelatihan, dari segi pelatih juga harus diperhatikan dengan tujuan materi yang diberikan mudah dipahami oleh peserta. Bahkan dalam memberikan kompensasi karyawan, juga harus sesuai dengan prinsip adil dan layak yang dapat menjadi acuan bagi manajemen untuk dilakukan dalam hal meningkatkan kinerja karyawan.

Berdasarkan dari data penilaian lapangan dan observasi yang dilakukan peneliti di PT Indo Suhar Jaya. Masih banyak karyawan yang memiliki kinerja yang kurang dari yang telah ditentukan oleh perusahaan. Ini disebabkan ada beberapa faktor yang menjadi penyebab kurangnya kualitas karyawan yang kurang memahami pekerjaan yang menjadi tanggung jawabnya. Faktor tersebut, dalam rekrutmen karyawan belum sesuai dengan standar dan system yang sudah menjadi acuan perusahaan tersebut serta belum sesuai dengan sistem yang ada. Kurangnya pelatihan yang diberikan oleh perusahaan baik karyawan baru maupun karyawan lama, serta kompensasi yang belum memadai, sehingga karyawan di perusahaan ini masih banyak karyawan yang memiliki kinerja yang kurang baik yaitu banyak karyawan yang tidak mentaati SOP, banyak karyawan yang sering terlambat atau mangkir, serta banyak karyawan yang mendapatkan nilai di bawah standar yang sudah ditetapkan oleh perusahaan. Perlu sekali adanya evaluasi dari cara pelaksanaan rektutmen, cara dan prosedur pemberian pelatihan, serta kompensasi yang perlu ditinjau lagi, apakah ada penyimpanganpenyimpangan prosedur sehingga kinerja karyawan kurang memadai.

Dari uraian yang sudah disampaikan, peneliti menduga rekrutmen, pelatihan, dan kompensasi yang tidak efektif menjadi penyebab kurang maksimalnya kinerja karyawan. Oleh karena itu peneliti tertarik untuk melakukan penelitian dengan judul "Pengaruh Rekrutmen, Pelatihan dan Kompensasi terhadap Kinerja Karyawan PT Indo Suhar Jaya Cabang Bogor”.

\section{TUJUAN PENELITIAN}

Tujuan penelitian yang ingin dicapai peneliti untuk mengetahui berapa besar 
pengaruh rekrutmen yang telah dilakukan dan berapa besar pelatihan bisa mempengaruhi serta bagaimanakah kompensasi yang diberikan di perusahaan terhadap karyawan sehingga bisa mempengaruhi kinerja karyawan PT Indo Suhar Jaya Bogor.

\section{TELAAH LITERATUR DAN PENGEMBANGAN HIPOTESIS}

Karyawan selalu berperan aktif dan dominan dalam setiap kegiatan organisasi, karena karyawan menjadi perencanaan, pelaku, dan penentu terwujudnya tujuan organisasi. Tujuan tidak mungkin terwujud tanpa peran aktif karyawan meskipun alat-alat yang dimilki perusahaan begitu canggih. Alatalat canggih yang dimiliki perusahaan tidak ada manfaatnya bagi perusahaan, jika peran karyawan tidak diikutsertakan. Manajemen Sumber Daya Manusia (MSDM) menjadi bagian dari manajemen yang fokus pada peranan pengaturan manusia dalam mewujudkan tujuan organisasi.

\section{Kepemimpinan}

Kaitannya dengan konsep kinerja merupakan kualitas dan kuantitas dari suatu hasil kerja (output) individu maupun kelompok dalam suatu aktivitas tertentu yang diakibatkan oleh kemampuan alami atau kemampuan yang diperoleh dari proses belajar serta keinginan untuk berprestasi.

Kinerja merupakan pencapaian yang optimal sesuai dengan potensi yang dimiliki seorang karyawan dalam melaksanakan tugas pokok dan fungsi yang berpedoman pada norma, standar operasional prosedur. Menurut Robbins (Mangkunegara, 2016) menyatakan bahwa kinerja karyawan adalah hasil dari pekerjaan karyawan yang terkait dengan tujuan organisasi, efisiensi, dan keefektifan kinerja lainnya.

Dalam penelitian ini indikator yang dipakai menurut Robbins (Mangkunegara, 2016) mengelompokkan dimensi kinerja pegawai menjadi sebagai berikut: 1) Kualitas kerja, diukur dari persepsi karyawan terhadap kualitas pekerjaan yang dihasilkan serta kesempurnaan tugas terhadap keterampilan dan kemampuan karyawan. Perilaku kerja ketika berada di tempat kerja dan melaksanakan pekerjaannya, pegawai melakukan dua jenis perilaku yaitu perilaku kerja dan perilaku pribadinya. 2) Kuantitas, merupakan jumlah yang dihasilkan, dinyatakan dalam istilah seperti jumlah unit, jumlah siklus aktivitas yang diselesaikan. 3) Ketepatan waktu, merupakan tingkat aktivitas diselesaikan pada awal waktu yang dinyatakan, dilihat dari sudut koordinasi dengan hasil output serta memaksimalkan waktu yang tersedia untuk aktivitas lain. 4) Efektivitas, merupakan tingkat penggunaan sumber daya organisasi (tenaga, uang, teknologi, bahan baku) dimaksimalkan dengan maksud menaikkan hasil dari setiap unit dalam penggunaan sumber daya. 5) Kemandirian, merupakan tingkat seorang karywan yang nantinya akan dapat menjalankan fungsi kerjanya. 6) Komitmen kerja, merupakan suatu tingkat dimana karyawan mempunyai komitmen kerja dengan instansi dan tanggung jawab karyawan terhadap pekerjaan. Dengan adanya kinerja yang baik tujuan perusahaan akan terwujud.

\section{Rekrutmen}

Rekrutmen merupakan suatu proses yang harus dilakukan oleh suatu perusahaan untuk memilih karyawan yang sesuai dengan tujuan perusahaan. Rekrutmen akan membawa dampak yang positif apabila dalam mencari karyawan menggunakan metode metode yang tepat, benar, dipakai dalam rekrutmen karyawan.

Sirait (2006), rekrutmen adalah merupakan serangkaian kegiatan yang dilakukan terencana, guna memperoleh calon-calon pegawai yang memenuhi syarat-syarat tertentu yang dituntut suatu jabatan tertentu yang dibutuhkan oleh organisasi.

Pelaksanaan rekrutmen tentunya tidak lepas dari proses rekrutmen, yang diawali dengan perencanaan sumber daya manusia karena adanya permintaan karyawan khusus dari pihak 
manajer divisi. Untuk mewujudkan permintaan manajer divisi perlu adanya lowongan pekerjaan yang tersedia bagi calon karyawan. Penempatan kerja sebelumnya akan dilakukan analisis informasi jabatan yang akan menentukan permintaan dan penempatan kerja yang diperlukan. Pengisian lowongan kerja bisa diambil dari dalam maupun luar organisasi atau perusahaan.

Rekrutmen menurut Sirait (2006), indikator dalam rekrutmen terdiri dari: 1) Proses Seleksi, serangkaian kegiatan yang dilakukan perusahaan atau organisasi untuk dapat mengambil keputusan tentang siapa-siapa dari mana calon pegawai yang tepat (memenuhi syarat) untuk bisa diterima menjadi pegawai. 2) Penempatan, suatu pengaturan awal atau pengaturan kembali dari seseorang atau lebih pegawai pada suatu jabatan yang berlainan. 3) Orientasi/sosialisasi merupakan penyesuaian diri baik secara psikis dan jasmani, psikologis, peranan (yang berhubungan dengan pekerjaan yang harus dilakukan).

\section{Pelatihan}

Pelatihan sangat perlu diberikan kepada semua karyawan, baik karyawan manajerial maupun karyawan operasional, tujuan pelatihan sangat bermanfaat bagi setiap karyawan untuk menambah wawasan, ilmu pengetahuan sesuai dengan bidang masing-masing. Sehingga karyawan mampu untuk menyelesaikan permasalahannya pekerjaan yang dihadapi.

Bangun (2012) pelatihan adalah proses mempertahankan atau memperbaiki keterampilan karyawan untuk menghasilkan pekerjaam yang efektif. Rivai (2004) pelatihan adalah bagian pendidikan yang menyangkut proses belajar untuk memperoleh dan meningkatkan keterampilan di luar sistem pendidikan yang lebih mengutamakan pada praktek daripada teori.

Indikator pelatihan yang digunakan dalam penelitian ini: 1) Materi Pelatihan, dengan mengetahui kebutuhan akan pelatihan, sebagai hasil dari langkah pertama dapat ditentukan materi pelatihan yang harus diberikan. 2) Metode Pelatihan, sesuai dengan materi pelatihan yang diberikan, maka ditentukanlah metode atau cara penyajian yang paling tepat. Penentuan atau pemilihan metode pelatihan tersebut didasarkan atas materi yang akan disajikan. 3) Pelatih (Instruktur), pelatih harus didasarkan pada keahlian dan kemampuannya untuk mentransformasikan keahlian tersebut pada peserta pelatihan. 4) Peserta pelatihan, agar program pelatihan dapat mencapai sasaran hendaknya para peserta dipilih yang benar-benar "siap dilatih" artinya mereka tenaga kerja yang diikutsertakan dalam pelatihan adalah mereka yang secara mental telah dipersiapkan untuk mengikuti program tersebut. Pada langkah ini harus selalu dijaga agar pelaksanaan kegiatan pelatihan benar-benar mengikuti program yang telah ditetapkan. 5) Sarana Pelatihan, sarana pendukung pelatihan dimaksudkan untuk mengukur kelebihan suatu program, kelengkapan, dan kondisi yang merupakan umpan balik untuk menilai atau menghasilkan output yang sesuai.

\section{Kompensasi}

Pada dasarnya manusia bekerja juga ingin memperoleh uang untuk memenuhi kebutuhan hidupnya. Untuk itulah seorang karyawan mulai menghargai kerja keras dan semakin menunjukkan loyalitas terhadap perusahaan dan karena itulah perusahaan memberikan penghargaan terhadap prestasi kerja karyawan yaitu dengan jalan memberikan kompensasi.

Kompensasi merupakan hak karyawan yang harus diberikan dari perusahaan kepada karyawan. Karyawan akan semakin giat bekerja apabila kompensasi yang didapatkan memadai untuk mencukupi kebutuhan setiap hari. Kompensasi yang didapatkan secara adil dan layak akan semakin meningkatkan kinerja karyawan.

Salah satu cara manajemen untuk meningkatkan prestasi kerja, meningkatkan pendidikan, dan meningkatkan kinerja para karyawan 
adalah malalui kompensasi (Mathis dan Jackson, 2000).

Kompensasi menurut Simamora (2004:442) merupakan imbalan finansial dan jasa nirwujud serta tunjangan yang diterima oleh para karyawan sebagai bagian dari hubungan kepegawaian. Kompensasi merupakan apa yang diterima oleh para karyawan sebagai ganti kontribusi mereka kepada organisasi.

Indikator kompensasi dalam penilaian ini menurut Simamora (2004:442) di antaranya adalah pertama, kompensasi finansial langsung, terdiri dari: a) Gaji balas jasa dalam bentuk uang yang diberikan oleh pihak perusahaan setiap bulannya kepada karyawan; b) Bonus merupakan pemberian uang yang diberikan oleh pihak perusahaan ketika karyawan dapat mencapai target yang telah ditetapkan sehingga memperoleh laba yang lebih besar; c) Upah lembur merupakan upah yang diberikan oleh pihak perusahaan atas pekerjaan yang dilaksanakan pada waktu kerja lembur.

Kedua kompensasi finansial tidak langsung, terdiri dari a) Asuransi kesehatan adalah suatu jaminan yang diberikan oleh perusahaan kepada karyawan apabila karyawan mengalami kecelakaan kerja. Yaitu merupakan salah satu bentuk perlindungan yang dilakukan oleh perusahaan untuk menjamin karyawannya dalam melakukan pekerjaan; b) Tunjangan Hari Raya (THR) yaitu tunjangan yang diberikan berupa uang kepada karyawan setiap tahun; c) Tunjangan uang makan merupakan tunjangan makan yang diberikan berupa uang kepada karyawan yang masuk kerja; d) Tunjangan transportasi merupakan tunjangan transportasi yang diberikan berupa uang kepada karyawan yang masuk kerja, terutama kepada karyawan yang bertugas di luar kantor.

\section{Pengaruh Rekrutmen terhadap Kinerja Karyawan}

Rekrutmen merupakan salah satu kegiatan yang sangat penting dalam manajemen sumber daya manusia. Keberhasilan pelaksanaan kegiatan rekrutmen akan menghasilkan sumber daya manusia yang berkualitas tinggi segaimana yang diharapkan organisasi. Rekrutmen merupakan jumlah dan kategori pegawai yang diperlukan yang ditetapkan dalam perencanaan pegawai atau pengelolan sumber daya manusia secara formal. Rekrutmen merupakan suatu proses untuk menarik kandidat, mencari pelamar kerja dengan kemampuan, keahlian, dan pengetahuan yang diperlukan organisasi guna memenuhi kebutuhan sumber daya manusia yang direncanakan oleh organisasi.

Rekrutmen hendaknya mempunyai efek domino, yakni dampak yang ditimbulkan menjadi positif dan membangun citra umum organisasi semakin baik dan bahkan pelamar yang gagal haruslah mempunyai kesan positif terhadap perusahaan tersebut. Pelaksanaan rekrutmen perlu dilakukan dengan cara hati-hati dan cerdas, akan menghasilkan sumber daya manusia yang mempunyai kinerja yang tinggi, sesuai dengan perencanaan yang dilaksanakan, sumber daya yang mampu bersaing, berkualitas tinggi, dan menjadi sumber daya yang akan mampu berkinerja dengan baik dan sesuai dengan tujuan dari rekrutmen. Hasil penelitian ini sesuai yang dilakukan oleh Nugroho (2012), Muayyidah (2015), dan Arif (2018). Maka dapat diduga bahwa rekrutmen berpengaruh positif terhadap Kinerja karyawan.

H1: Rekrutmen berpengaruh positif terhadap kinerja karyawan pada PT Suhar Jaya Cabang Bogor.

\section{Pengaruh Pelatihan terhadap Kinerja Karyawan}

Pelatihan dapat membantu karyawan dalam mengembangkan berbagai keterampilan yang dibutuhkan untuk menjalankan organisasi, yang secara langsung akan mempengaruhi pekerjaan karyawan di suatu organisasi, di samping itu pelatihan juga akan memberikan dampak positif kepada karyawan untuk belajar dan berkembang sehingga dapat menciptakan lingkungan pekerjaan yang positif. Yang mendukung strategi bisnis organisasi. 
Pelatihan merupakan tanggung jawab bersama antara karyawan dan organisasi. Karyawan berkewajiban mengikuti pelatihan yang sudah dirancang oleh organisasi agar karyawan dapat bekerja dengan profesional, bersemangat, dan berdedikasi tinggi sehingga dapat mengoptimalkan kinerjanya. Sesuai dengan penelitian yang dilakukan oleh Aruan (2013), Mutmainah (2013), dan Rahmayani \& Prasetya (2014). Karyawan adalah aset utama dari suatu organisasi dimana pelatihan sangat diperlukan untuk kemajuan organisasi yang akan datang. Dengan pelatihan yang terstuktur karyawan akan mempunyai kinerja yang lebih bagus sesuai dengan perencanaan organisasi. Maka dapat diduga bahwa pelatihan berpengaruh positif terhadap kinerja karyawan.

H2: Pelatihan berpengaruh positif terhadap kinerja karyawan pada PT Suhar Jaya Cabang Bogor.

\section{Pengaruh Kompensasi terhadap Kinerja Karyawan}

Kompensasi merupakan salah satu faktor penting dalam suatu organisasi dan karyawan. Kompensasi salah satu alasan kenapa dan motivasi utama mengapa orang mau bekerja. Orang bekerja bukan semata-mata ingin mengabdikan diri untuk perkembangan organisasi, melainkan mendapatkan tujuan yang ingin dicapai yaitu dengan mengharapkan imbalan atas jasa yang telah dikerjakan.

Salah satu cara manajer untuk meningkatkan kinerja karyawan dengan memberikan kompenasi yang tepat. Dimana kompensasi merupakan hak karyawan sebagai imbalan atas jasa yang diberikan kepada perusahaan atau organisasi. Keberhasilan organisasi dalam menetapkan kompensasi yang layak dan adil akan menentukan kualitas dari karyawan dalam bekerja, yang secara langsung berkaitan dengan efektifitas tujuan karyawan dan efisiensi anggaran organisasi. Semakin tinggi kompensasi atau balas jasa yang diberikan suatu organisasi kepada karyawannya semakin tinggi kinerja karyawan tersebut. Sesuai dengan penelian yang dilakukan oleh Kasenda (2013), Rismawati (2016), serta didukung penelitian yang dilakukan Rukmini \& Hendriani (2017), maka dapat diduga bahwa kompensasi sangat berpengaruh positif terhadap kinerja karyawan pada PT Suhar Jaya Cabang Bogor.

H3: Kompensasi berpengaruh positif terhadap kinerja karyawan pada PT Suhar Jaya Cabang Bogor.

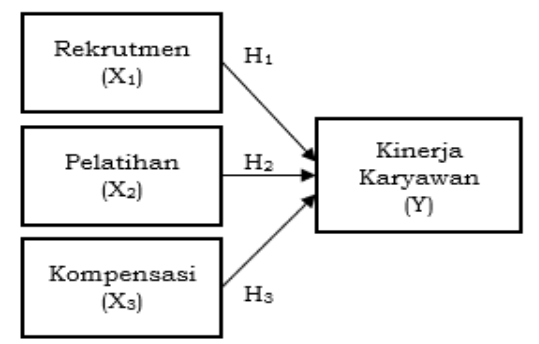

Gambar 1. Kerangka Pemikiran

\section{METODE PENELITIAN}

Dalam penelitian ini peneliti menggunakan penelitian deskriptif dengan pendekatan kuantitatif. Penelitian kuantitatif merupakan suatu pendekatan penelitian yang bersifat obyektif, yang menekankan pada pengujian teori-teori dengan melalui pengukuran variabel penelitian dengan menggunakan angka dan melakukan analisis data dengan metode pengujian statistik.

\section{Sampel Penelitian}

Menurut Sudjana \& Ibrahim (2004:85), menyatakan bahwa sampel adalah sebagian dari populasi terjangkau yang memiliki sifat yang sama dengan populasi. Untuk mencari jumlah sampel dapat menggunakan teknik slovin. Sampel peniitian berjumlah 52 dari 110 populasi dengan marjin error 10 persen.

\section{Desain Penelitian}

Penelitian yang digunakan adalah explanatory research yang menjelaskan hubungan kausal antara variabelvariabel penelitian melalui pengujian hipotesis (Singarimbun \& Effendi, 2009) dengan menggunakan pendekatan kuantitatif. Penelitian ini menjelaskan pengaruh antara variabel independen rekrutmen $\left(\mathrm{X}_{1}\right)$, pelatihan $\left(\mathrm{X}_{2}\right)$, dan 
kompensasi $\left(\mathrm{X}_{3}\right)$ apakah mempunyai pengaruh terhadap variabel dependen, kinerja karyawan $(\mathrm{Y})$.

\section{Operasionalisasi Variabel}

Operasionalisasi variabel penelitian dapat dikemukakan sebagai berikut:

\section{Tabel 1. Operasionalisasi Variabel}

\begin{tabular}{|c|c|c|}
\hline Variabel/Konsep & Indikator & Skala \\
\hline \begin{tabular}{|l|} 
Kinerja Karyawan (Y) \\
Hasil dari pekerjaan \\
karyawan yang terkait \\
dengan tujuan organisasi, \\
efisiensi, dan kinerja \\
kefektifan kinerja lainnya. \\
(Mangkunegara, 2016)
\end{tabular} & $\begin{array}{ll}\text { 1. } & \text { Kualitas kerja } \\
\text { 2. } & \text { Kuantitas } \\
\text { 3. } & \text { Ketepatan } \\
\text { waktu. } \\
\text { 4. } & \text { Efektivitas } \\
\text { 5. } & \text { Kemandirian } \\
\text { 6. } & \text { Komitmen } \\
\end{array}$ & $1-5$ \\
\hline \begin{tabular}{|l|} 
Rekrutmen $\left(\mathbf{X}_{\mathbf{1}}\right)$ \\
Serangkaian kegiatan yang \\
dilakukan terencana, guna \\
memperoleh calon-calon \\
pegawai yang memenuhi \\
syarat-syarat tertentu yang \\
dituntut suatu jabatan \\
tertentu yang dibutuhkan \\
oleh organisasi. \\
(Sirait, 2006) \\
\end{tabular} & $\begin{array}{ll}\text { 1. } & \text { Proses } \\
\text { 2. } & \text { Seleksi } \\
\text { 3. } & \text { Penempatan } \\
\text { 4. } & \text { Orientasi }\end{array}$ & $1-5$ \\
\hline $\begin{array}{l}\text { Pelatihan }\left(\mathbf{X}_{2}\right) \\
\text { Bagian pendidikan yang } \\
\text { menyangkut proses belajar } \\
\text { untuk memperoleh dan } \\
\text { meningkatkan keterampilan } \\
\text { di luar sistem pendidikan } \\
\text { yang lebih mengutamakan } \\
\text { pada praktek daripada } \\
\text { teori. } \\
\text { (Rivai, 2005) }\end{array}$ & 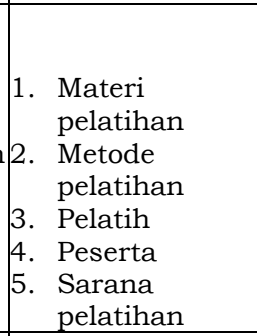 & $1-5$ \\
\hline $\begin{array}{l}\text { Kompensasi }\left(\mathbf{X}_{3}\right) \\
\text { Imbalan finansial dan jasa } \\
\text { nirwujud serta tunjangan } \\
\text { yang diterima oleh para } \\
\text { karyawan sebagai bagian } \\
\text { dari hubungan } \\
\text { kepegawaian. Kompensasi } \\
\text { merupakan apa yang } \\
\text { diterima oleh para } \\
\text { karyawan sebagai ganti } \\
\text { kontribusi mereka kepada } \\
\text { organisasi }\end{array}$ & \begin{tabular}{|l} 
1. Kompensasi \\
finansial \\
langsung \\
a. Gaji \\
b. Bonus \\
c. Upah \\
2. Kompensasi \\
tidak \\
langsung \\
a. Asuransi \\
kesehata \\
b. Tunjangan \\
Hari Raya \\
c. Tunjangan \\
makan \\
d. Tunjangan \\
Transport.
\end{tabular} & $1-5$ \\
\hline
\end{tabular}

\section{Metode Analisis}

Data penelitian yang digunakan adalah data primer dan data sekunder. Sumber data primer yang digunakan yaitu kuesioner penulis memberikan pertanyaan langsung kepada responden dan observasi langsung, peneliti mengamati responden di lapangan. Sedangkan data sekunder adalah data yang diperoleh secara tidak langsung melalui perantara media seperti buku, jurnal penelitian, serta internet.

\section{Uji Validitas}

Menurut Sarjono \& Julianita 2011, uji validitas yaitu suatu alat yang digunakan untuk mengukur derajat ketepatan antara data yang terjadi pada obyek penelitian dengan data yang dapat dilaporkan oleh peneliti. Uji validitas dilakukan dengan membandingkan antara nilai $r$ hitung terhadap $r$ table untuk tingkat signifikan 5\%. Jika $r$ hitung > r table $(0,60)$ maka pertanyaan atau indikator tersebut dinyatakan valid, demikian sebaliknya bila $r$ hitung $<\mathrm{r}$ table $(0,60)$ maka pertanyaan atau indikator dinyatakan tidak valid.

\section{Uji Reliabilitas}

Menurut Sarjono \& Julianita (2011), reliabilitas adalah suatu alat untuk mengukur suatu kuesioner yang merupakan indikator dari variabel penelitian. Suatu kuesioner dikatakan reliabel jika jawaban seseorang terhadap pernyataan adalah konsisten atau stabil dari waktu ke waktu. Uji reliabilitas dilakukan terhadap keseluruhan butir pernyataan yang telah valid. Uji reliabilitas jika nilai Cronbach's Alpha > 0,60 .

\section{Uji Asumsi Klasik}

Dalam penelitian ini uji asumsi klasik yang digunakan uji normalitas, multikolinieritas, autokorelasi, dan heteroskedastisitas.

\section{Analisis Regresi Linier Berganda}

Analisis berganda digunakan untuk mengetahui seberapa besar pengaruh antara variabel bebas rekrutmen $\left(\mathrm{X}_{1}\right)$, pelatihan $\left(\mathrm{X}_{2}\right)$, dan kompensasi $\left(\mathrm{X}_{3}\right)$ terhadap variabel terikat yaitu kinerja karyawan (Y).

\section{Uji Hipotesis}

Pengujian hipotesis dilakukan untuk menguji kebenaran hipotesis, yang diajukan apakah pengaruh rekrutmen, pelatihan, dan kompensasi mempunyai 
pengaruh terhadap kinerja atau apakah hipotesis tersebut diterima atau ditolak. Uji statistik $t$ digunakan untuk mengetahui apakah ada pengaruh secara parsial antara variabel independen terhadap variabel dependen. Uji statistik ini dilakukan dengan tingkat signifikan 5\% $(0,05)$ (Priyatno, 2013).

Hipotesis Ho: $b_{1}=0$ artinya tidak ada pengaruh secara parsial antara variabel independen $\mathrm{X}_{1}$ terhadap variabel dependen Y.

Hipotesisi Ha: $b_{1} \neq 0$ artinya ada pengaruh secara parsial antara variabel independen $\mathrm{X}_{1}$ terhadap $\mathrm{Y}$.

\section{HASIL DAN PEMBAHASAN Hasil Penelitian \\ Uji Validitas dan Reliabilitas Rekrutmen $\left(X_{1}\right)$}

Hasil uji validitas variabel $X_{1}$ (rekrutmen) yang dilakukan dari 10 pertanyaan yang diajukan Corrected Item-Total Correlation > 0,273 untuk seluruh item, maka dari 10 item pernyataan variabel $\mathrm{X}_{1}$ (rekrutmen) seluruhnya valid.

Uji reliabilitas yang dilakukan didapat nilai Cronbach's Alpha > 0,6. Hasil uji mendapatkan nilai Cronbach's Alpha lebih besar dari nilai kritis $(0,910>$ $0,6)$ maka variabel $X_{1}$ (rekrutmen) reliabel.

\section{Uji Validitas dan Reliabilitas Pelatihan $\left(\mathrm{X}_{2}\right)$}

Hasil uji validitas variabel $\mathrm{X}_{2}$ (pelatihan) yang dilakukan dari 10 pertanyaan yang diajukan Corrected Item-Total Correlation > 0,273 untuk seluruh item, maka dari 10 item pernyataan variabel $\mathrm{X}_{2} \quad$ (pelatihan) seluruhnya valid.

Sedangkan uji reliabilitas memenuhi persyaratan reliabel. Hal ini dibuktikan dari nilai Cronbach's Alpha sebesar 0,931 dan dapat dinyatakan bahwa lebih besar nilai kritis $(0,931>0,60)$ dapat dikatakan $\mathrm{X}_{2}$ (pelatihan) reliabel.

\section{Uji Validitas dan Reliabilitas Kinerja Karyawan (Y)}

Hasil uji validitas variabel Y (kinerja) yang dilakukan dari 10 pertanyaan yang diajukan Corrected Item-Total Correlation $>0,273$ untuk seluruh item, maka dari 10 item pernyataan variabel Y (kinerja) seluruhnya valid.

Sedangkan uji reliabilitas memenuhi persyaratan reliabel data. Hal ini dibuktikan dari nilai Cronbach's Alpha sebesar 0,857 dan dapat dinyatakan bahwa nilai $0,857>0,60$ (reliabel). Sehingga dapat dikatakan kinerja karyawan reliabel.

\section{Uji Asumsi Klasik}

Output uji asumsi, diketahui nilai signifikasi untuk $\mathrm{X}_{1}$ (rekrutmen) sebesar 2,284, $\mathrm{X}_{2}$ (pelatihan) sebesar 5,913, $\mathrm{X}_{3}$ (kompensasi) 11,761 dan Y (kinerja) sebesar 0,266 lebih besar dari 0,5, dapat disimpulkan data tersebut diuji berdistribusi normal.

Tabel 2. Model Summaryb

\begin{tabular}{|l|c|l|l|l|}
\hline Model & $\mathrm{R}$ & $\mathrm{R}$ Square & $\begin{array}{l}\text { Adjusted } \\
\text { R Square }\end{array}$ & $\begin{array}{c}\text { Std. Error of } \\
\text { the Estimate }\end{array}$ \\
\hline 1 & $.918 \mathrm{~s}$ & .844 & .834 & 1.643 \\
\hline
\end{tabular}

Predictors: (Constant), KOMPENSASI,

REKRUTMEN, PELATIHAN

Sumber: Data penelitian diolah, 2020

Tabel 2 menunjukkan hasil bahwa nilai R Square sebesar 0,844 maka 84,4\% variabel rekrutmen, pelatihan, dan kompensasi mempengaruhi kinerja karyawan. Sedangkan sisanya 15,6\% dipengaruhi oleh variabel lain yang tidak diteliti. Analisis berikutnya berupa tabel Anova yang digunakan untuk menguji hipotesis keempat yaitu pengaruh rektutmen, pelatihan, dan kompensasi terhadap kinerja.

\section{Analisis Korelasi Berganda}

Tabel 3. Analisis Regresi Linear Berganda

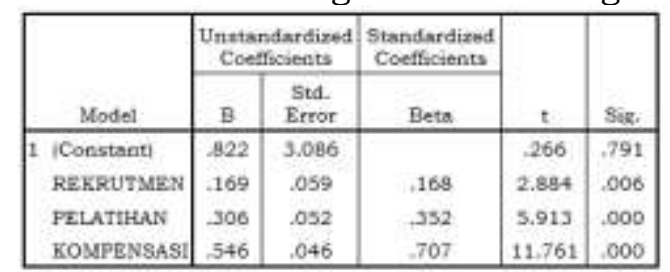

Sumber: Data penelitian diolah, 2020

Analisis regresi linier ganda juga menghasilkan koefisien yang menunjukkan pengaruh simultan rektutmen, pelatihan, dan kompensasi 
terhadap kinerja karyawan. Diperoleh persamaan sebagai berikut: $\hat{Y}=0,822+$ $0,169 \mathrm{X} 1+0,306 \mathrm{X} 2+0,546$

Dari persamaan di atas dapat diartikan apabila dengan nilai konstanta sebesar 0,822, akan semakin baik, jika asumsi variabel lain konstan, maka rekrutmen, pelatihan, dan kompensasi dapat meningkatkan kinerja karyawan PT Indo Suhar Jaya Bogor semakin baik. Koefisien regresi $\left(\mathrm{X}_{1}\right)$ rekrutmen sebesar 0,169 berpengaruh positif terhadap (Y) kinerja karyawan PT Indo Suhar Jaya Bogor, dapat diartikan semakin baik rekrutmen PT Indo Suhar Jaya Bogor meningkatkan kinerja karyawan (Y). Hasil regresi tersebut terlihat $\left(\mathrm{X}_{2}\right)$ pelatihan dan $\left(\mathrm{X}_{3}\right)$ kompensasi berpengaruh lebih tinggi dibandingkan $\left(\mathrm{X}_{1}\right)$ rekrutmen terhadap kinerja karyawan PT Indo Suhar Jaya Bogor.

Dapat disimpulkan semakin baik pelatihan, kompensasi yang diberikan dan semakin baik dalam rekrutmen karyawan akan meningkatkan kinerja karyawan PT Indo Suhar Jaya Bogor.

\section{Uji Kelayakan Model (Uji Statistik)}

Hasil uji $F$ sebesar tingkat probabilitas 0,000 membuktikan model persamaan regresi hasil analisis layak digunakan untuk memprediksi pengaruh antar variabel. Hal ini karena dalam model persamaan regresi rekrutmen, pelatihan, dan kompensasi mampu menjelaskan 0,822 bisa dikatakan layak dilanjutkan.

\section{Uji t (Uji Hipotesis secara Parsial)}

Dari hasil uji signifikan $\left(\mathrm{X}_{1}\right)$ rekrutmen terhadap $(\mathrm{Y})$ kinerja karyawan PT Indo Suhar Jaya Bogor diperoleh nilai t hitung 86,256 dan sig t hitung $=0,000$ < 0,05 dapat disimpulkan variable penelitian secara bersama-sama perpengaruh positif terhadap kinerja karyawan PT Indo Suhar Jaya Bogor.

\section{Pembahasan}

\section{Pengaruh Rekrutmen terhadap} Kinerja Karyawan

Hasil penelitian ini menyatakan bahwa terdapat pengaruh signifikan rekrutmen terhadap kinerja karyawan. thitung $2.884>$ t-tabel 2.009 dan nilai signifikansi $0,006<$ nilai probabilitas 0,05, maka dapat disimpulkan hasil penelitian ini menunjukkan bahwa rekrutmen berpengaruh signifikan terhadap kinerja karyawan di PT Indo Suhar Jaya Bogor. Hasil penelitian ini sejalan dengan penelitian yang dilakukan oleh Nugroho (2012), dan Arif (2018) dengan hasil penelitiannya yang menyatakan bahwa secara parsial rekrutmen berpengaruh signifikan terhadap kinerja karyawan. Semakin baik system rekrutmen yang digunakan dan menggunakan metode yang tepat akan semakin baik kinerja karyawan.

\section{Pengaruh Pelatihan terhadap Kinerja Karyawan}

Hasil penelitian ini menyatakan bahwa terdapat pengaruh signifikan pelatihan terhadap kinerja karyawan. Hasil penelitian ini menunjukkan bahwa pelatihan berpengaruh signifikan terhadap kinerja karyawan di PT Indo Suhar Jaya Bogor. Hasil penelitian ini sejalan dengan penelitian yang dilakukan oleh Safitri (2013), dan Prasetyo (2016) dengan hasil penelitiannya yang menyatakan bahwa secara parsial pelatihan berpengaruh signifikan terhadap kinerja karyawan. Pelatihan sangat dibutuhkan setiap karyawan. Pelatihan karyawan sering dilakukan atau pemberian pelatihan yang terstuktur dengan pelatih yang mempunyai kualitas yang baik metode yang handal akan meningkatkan kinerja karyawan.

\section{Pengaruh Kompensasi terhadap Kinerja Karyawan}

Hasil penelitian ini menyatakan bahwa terdapat pengaruh signifikan kompensasi terhadap kinerja karyawan. Hasil penelitian ini menunjukkan bahwa kompensasi berpengaruh signifikan terhadap kinerja karyawan di PT Indo Suhar Jaya Bogor. Hasil penelitian ini sejalan dengan penelitian yang dilakukan oleh Kasenda (2013) dan Ratnasari (2016) dengan hasil penelitiannya yang menyatakan bahwa secara parsial kompensasi berpengaruh signifikan terhadap kinerja karyawan. Kompensasi yang diberikan kepada setiap karyawan 
yang adil dan layak serta menghargai keahlian keryawan dan menggunakan prinsip-prinsip yang benar akan semakin tinggi kinerja karyawan.

\section{KESIMPULAN \\ Kesimpulan}

Penilitian yang dilakukan di PT Suhar Jaya cabang Bagor bahwa rektutmen yang dilakukan sesuai dengan metode yang mengacu pada aturan perusahaan yang sudah ditetapkan, serta pemberian pelatihan yang tersruktur, dengan menggunakan prinsip-prinsip ditentukan dalam program pelatihan, serta kompensasi yang diberikan dengan asas adil dan layak serta sesuai dengan aturan dari organisasi bisa meningkatkan kinerja karyawan secara signifikan. Semakin tinggi ketiga variable tersebut dilaksanakan semakin tinggi kinerja karyawan.

\section{Saran}

Dalam pengadaan rekrutmen, pemberian pelatihan, serta pemberian kompensasi yang sudah dilaksanakan dengan baik sesuai dengan aturan perusahaan hendaknya selalu dievaluasi dengan supaya kinerja karyawan yang sudah baik akan tetap terjaga.

\section{DAFTAR PUSTAKA}

Arif, M. (2018). Analisis Rekrutmen dan Penempatan Kerja terhadap Kinerja Karyawan pada Hotel Oase. AlHikmah: Jurnal Agama dan Ilmu Pengetahuan, 15(1), 42-63.

Aruan, D. N. (2013). Pengaruh Pelatihan Kerja dan Motivasi terhadap Kinerja Karyawan PT Sucofindo (Persero) Surabaya. Jurnal Ilmu Manajemen (JIM), 1(2), 565-574.

Bangun, W. (2012). Manajemen Sumber Manusia, Jakarta: Erlangga.

Kasenda, R. (2013). Kompensasi dan Motivasi Pengaruhnya terhadap Kinerja Karyawan pada PT Bangun Wenang Beverages Company Manado. Jurnal EMBA: Jurnal Riset Ekonomi, Manajemen, Bisnis dan Akuntansi, 1(3).
Mangkunegara, A. A. A. P. (2016). Manajemen Sumber Daya Manusia Perusahaan. Bandung: PT Remaja Rosdakarya.

Mathis, R. L., \& Jackson, J. H. (2000). Manajemen Sumber Daya Manusia. Jakarta: Salemba Empat.

Muayyidah, L. (2015). Analisisi Sistem Rekrutmen dan Pelatihan dalam Meningkatkan Kinerja Karyawan di BMT UGT Pusat Sidogiri Bangil. Doctoral Dissertation.

Mutmainah, H. (2013). Pengaruh Kompensasi, Pelatihan, dan Peran Supervisor terhadap Kinerja yang Dimediasi oleh Kepuasan Kerja pada Karyawan Paguyuban Batik Laweyan Surakarta. GRADUASI 29.

Nugroho, M. A. (2012). Pengaruh Proses Rekrutmen dan Seleksi terhadap Kinerja Karyawan pada PT. Angkasa Pura I (Persero) Bandara Internasional Sultan Hasanuddin Makassar. Doctoral Dissertation.

Rismawati, A. (2016). Pengaruh Motivasi Berprestasi, Promosi Jabatan, dan Kompensasi terhadap Kinerja Karyawan di LKS Asri Tulung Agung. Skripsi.

Rivai, V. (2004). Manajemen Sumber Daya Manusia Untuk Perusahaan. Jakarta: PT Raja GrafindoPersada.

Rukmini, E., \& Hendriani, S. (2017). Pengaruh Kompensasi, Lingkungan Kerja, dan Pengembangan Karir terhadap Kepuasaan Kerja dan Turnover Intention (studi pada Karyawan MNC Bank Wilayah Sumatera. Jurnal Tepak Manajemen Bisnis, 9(1), 645-661.

Safitri, E. (2013). Pengaruh Pelatihan dan Disiplin Kerja terhadap Kinerja Karyawan. Jurnal Ilmu Manajemen (JIM), 1(4).

Sirait, J. T. (2016). Memahami Aspekaspek Pengelolaan Sumber Daya Manusia dalam Organisasi. Jakarta: Grasindo.

Simamora, H. (2004). Manajemen Sumber Daya Manusia. Yogyakarta: STIE YKPN.

Singarimbun, M., \& Effendi, S. (2009). Metode Penilaian Survai. Jakarta: LP3ES. 